\title{
The 'Tribal Politics' of Field Research: A Reflection on Power and Partiality in 21st-Century Warzones
}

\author{
Romain Malejacq and Dipali Mukhopadhyay
}

\begin{abstract}
Can fieldwork still be done in today's most violent warzones? We contend that long-held methodological principles about power and impartiality do not hold in today's conflict-ridden environments. Research of this kind can still be pursued, but only if the scholar's place is reconceived as one of limited power and unavoidable partiality. We argue that those still able to do fieldwork in sites of increasing danger do so by virtue of building their own 'tribes,' forming and joining different social micro-systems to collect data and, in some cases, survive. Field research must, therefore, be recognized as its own form of foreign intervention. In considering the future of political science research in the most challenging war-torn settings, we examine the risks and opportunities that accompany 'tribal politics' of this kind and underline the importance of reflecting on our own positionality in the process of knowledge production.
\end{abstract}

$T$ he formative conflicts of the $21^{\text {st }}$ century have bewildered statesmen, generals, aid workers, and journalists in profound and unprecedented ways. They have also challenged students of political violence, state formation, and intervention, who are left wondering whether it is advisable, or even possible, to pursue answers to their questions through fieldwork under increasingly difficult circumstances. Although this is not a novel dilemma, $21^{\text {st }}$-century conflicts introduce new challenges for qualitative field researchers. With the rise of political violence aimed at Westerners of all stripes, recent trends have made venturing into certain places more dangerous than ever before. ${ }^{1}$

With the end of the Cold War, a new kind of conflict has become commonplace, shaped by the forces of globalization. These "new wars," populated by state and non-state armed actors, involve military and criminal violence against civilians. ${ }^{2}$ The latest generation of these wars also involves ideological and identity-based struggles that make for challenging spaces within which to conduct research. As Julie Mertus wrote: "Entering insecure areas $\ldots$ is particularly risky today, given the post-Cold War

Romain Malejacq is assistant professor at the Centre for International Conflict Analysis \& Management (CICAM), Radboud University Nijmegen, Institute for Management Research (r.malejacq@fm.ru.nl). His research focuses on violence, political order, and state formation and the nature of alternative power structures in conflict environments like Afghanistan and Somalia. Dipali Mukhopadhyay is assistant professor at Columbia University's School of International and Public Affairs and a member of the Saltzman Institute of War and Peace Studies (dm2917@columbia.edu). Her research focuses on political violence, state-building, and foreign intervention in Afghanistan and Syria, and she recently published Warlords, Strongman Governors and the State in Afghanistan (Cambridge University Press) in 2014. The authors are listed in alphabetical order and contributed equally to this article. Earlier versions of this article were presented at the Central Eurasian Studies Society's 2015 annual conference, Wageningen University's Sociology of Development and Change Group "Fieldwork in Conflict and Post-conflict Settings" seminar, Ghent University's Conflict Research Group "Methods \& Ethics in Fieldwork" research seminar, and Princeton University's Department of Politics "Qualitative Methods and International Relations" graduate seminar, where the authors received excellent comments. They are grateful for research assistance from John Jacobs, Christy Provines, and Ilse Renkens and feedback and suggestions from Séverine Autesserre, Jennifer Brick-Murtazashvili, Sarah Bush, Susanna Campbell, Christopher Day, Deedee Derksen, Jesse Driscoll, Kimberly Howe, Sean Lee, David Mansfield, Aarya Nijat, William Reno, and Keren Yarhi-Milo. The authors also wish to thank the European Commission (Marie Curie Individual Fellowship, project 661644) and New York University's Center on International Cooperation for their financial support. 
shift to intra-state conflicts, and the rise in terrorist activity and other non-state or trans-state violence." 3

Social scientists have articulated important concerns about the conduct of field research amidst conflict. ${ }^{4}$ Some have concentrated on the ethical implications of the pursuit; ${ }^{5}$ others have focused on the practicalities. ${ }^{6}$ Still, it remains commonplace for political scientists to abstain from delving into the details of how they arrived at their claims. ${ }^{7}$ Researchers are often the "lone rangers, cowboys, individualists" that Gary Fine took to task twenty years ago. In the context of ongoing debates on transparency in political science, we wish to resurrect the notion that the "curtain" shielding fieldwork from greater scrutiny must be pulled back for a more honest conversation about the challenges involved in pursuing this brand of scholarship today. ${ }^{8}$

We contend that long-held methodological principles about positionality do not hold in today's conflicts. Research of this kind can still be pursued, but only if the scholar's place in the political economy of today's wars is reconceived as one of limited power and unavoidable partiality. We build on a long social scientific tradition of reflexivity, attempting to better understand the impact of our own profiles on the scholarship we produce. We argue that those still able to do fieldwork amidst increasing violence do so by virtue of building their own 'tribes,' forming and joining different social micro-systems to collect data and, in some cases, survive. We conclude that field research must be recognized as a form of intervention, with analogs to other types of intervention-from humanitarian aid delivery to counterinsurgency - and a corresponding set of challenges and opportunities.

Our objective is to engage frankly with the evolving realities of conducting research in war-torn countries in all of their untidy complexity. We do not aim to establish standards nor to develop new methodological tools. Instead, we add our contemporary concerns to a longstanding conversation amongst scholars whose areas of interest have coincided with "the primary geopolitical focus of US foreign policy." We attempt to reflect critically on our own experiences_-in the "greater" Middle East ${ }^{10}$ - and to join other scholars in encouraging greater reflexivity in the discipline. ${ }^{11} \mathrm{We}$ imagine that students of foreign aid, the criminal justice system, authoritarian governance, and Congressional politics - to name a few - might also benefit from considering whether their suppositions about their own position, vis-à-vis their subjects and interlocutors, remain well-founded.

While this kind of exercise is commonplace in other disciplines, political scientists have largely avoided meditations of this sort, often presenting their claims in positivist terms. The positivist and neopositivist traditions of empirical research are centered around notions of positionality that can preclude a researcher's steady (re)consideration of her place within the research environment. "Such an epistemology," Kim England noted, "is supported by methods that position the researcher as an omnipotent expert in control of both passive research subjects and the research process." 12 This view, in fact, lends itself to the notion that the researcher's ideal (and achievable) place is one of total power and impartiality.

And, yet, to reflect on one's role as researcher in the creation of knowledge is to address one's subjectivity, fallibility, and influence on the learning endeavor. ${ }^{13}$ The practice of reflexivity can be a humbling one, as the researcher comes to terms with the fluidity and tenuousness of her position, but in fact, "the meaning-making activity of human actors is central to understanding significant dimensions of causality that are obscured in positivist epistemological and ontological conceptions of that key idea."14

We take note of Lisa Wedeen's observation that political science has largely relegated reflexivity to mere "navel gazing" 15 and reconsider our own positions within the systems we study. We have spent our scholarly careers heretofore studying warlordism, rebel politics, and foreign interventions in Afghanistan, Somalia, and the TurkeySyria borderland. Our research concerns itself with the "marketplaces" that comprise political, social, and economic life in warzones that have been intervened upon by foreign actors. ${ }^{16}$ We focus, more specifically, on the political and military elites whose resources, interests, and actions consequentially shape state-society relations.

As qualitative students of political violence, we have engaged elites as research subjects as well as informants in hundreds of semi-structured interviews. Our interviewees have included warlords, elders, businessmen, police chiefs, governors, elected politicians, opposition leaders, civil society activists, and senior-most bureaucrats. ${ }^{17}$ Our research experiences have forced us to question canonical conceptions of power and impartiality and to conclude, contrary to some key methodological presuppositions, that we are often neither powerful nor impartial when conducting fieldwork amidst political violence. Those still doing fieldwork in increasingly dangerous warzones do so by virtue of building their own tribes. We argue that this kind of fieldwork can be understood as a kind of intervention, redolent with resultant risks and dilemmas.

Judith Stacey described fieldwork as "an intrusion and intervention into a system of relationships." 18 "Researchers, like aid agencies," Jonathan Goodhand cautioned, "need to be aware of how their interventions may affect the incentive systems and structures driving violent conflict or impact upon the coping strategies and safety of communities."19 The strategies, myths, and mistakes of diplomatic, humanitarian, and military intervention in fact have clear analogs in the arena of scholarly intervention. Ironically, scholars studying today's warzones - especially research with elites - risk falling into some of the same traps that they seek to expose.

This article is divided into four sections. First we argue that political scientists ought to reconsider two related 
imperatives of fieldwork: the power paradigm that assumes an asymmetry between researcher and informant in favor of the former; and the notion that researchers can and must remain impartial in the midst of conflict. We contend that those who conduct fieldwork in conflictridden environments must recognize their own positionality as marked by limited power and unavoidable partiality. ${ }^{20}$ Second, we develop the notion of 'tribebuilding' as a metaphor for the method we and others pursue to do fieldwork amidst increasing violence, and reflect on the risks of this tribe-building endeavor. Third, we consider the future of political science research in the most challenging war-torn settings, but also the opportunities for innovation that exist. We share some lessons from our own efforts to mitigate against the risks of these 'tribal politics.' We conclude by considering the broader implications of our argument for the discipline's ongoing conversation about transparency and replicability.

\section{Rethinking Power and (Im)Partiality in the Field}

\section{On Power}

Researchers have been taught that they hold power over their 'subjects' simply by introducing them into conversation and, therefore, must carefully wield those responsibilities. One basis for this belief is the legacy of medical and psychological experimental research and its concern with human subjects protection, whereby the 'researcherresearched' relationship could be reduced to "the knowledgeable and powerful experimenter" and "the ignorant and powerless subject." 21 Another basis for this paradigm is the historic scaffolding upon which relations between the Occident and its 'exotic' objects of study were built. This historical dynamic has translated into assumptions about the investigator's responsibility for and power over her subject. ${ }^{22}$

Those who collect the opinions and narratives of others do have certain powers that bear recognition. Intuitively, this is especially true for researchers working in countries where their home governments have 'boots on the ground.' In Afghanistan, for example, we had the capacity to offer tangible support to those we met. ${ }^{23}$ In addition to our financial assets, we had cultivated forms of social capital in Kabul that afforded us knowledge and connections otherwise unavailable to our contacts in the countryside. Our networks extended back to our home countries, where we were in a position-real or perceived - to support Afghans seeking access to university admission, scholarships, asylum applications, employment, and the policymaking establishment. Arguably, this imbalance of power might be further exacerbated by researchers who "alter the setting, scenery, and sometimes life chances of individuals" 24 through more intrusive methods.

There is also an "imperialism of knowledge production" in which all academics take part. ${ }^{25}$ Researchers have the power to transmit (and distort) the thoughts of others. ${ }^{26}$ There is a risk implicit in an informant's sharing of his story with a researcher since he has no control over her subsequent interpretation. ${ }^{27}$ There are also risks that arise once a researcher publishes her work, whereby those who contributed to the research might suffer consequences. ${ }^{28}$ The work might also be utilized by governments toward ends that may not have been intended by its author. $^{29}$

A researcher can try to mitigate these risks; Jesse Driscoll, for example, chose not to include a list in his book of the Tajik commanders he studied to avoid offering up a "targeting list." 30 The formal omission of this list could not, of course, prevent officials from extracting information from the publication or those still in Tajikistan who contributed to the project; in many ways, these risks reflect the powerlessness of a researcher once findings are released. Séverine Autesserre explained, for example, how her work had been used by politicians on both sides of the Rwanda-Congolese border to opposite ends: "I have no idea of what I could have done (or could do) to prevent this kind of manipulation." 31

As such, a number of scholars have called into question the 'researcher as powerful, researched as powerless' paradigm and underscored the reality that their kith are often the less powerful parties in this dyad. Fieldwork that involves participant observation and interviews can only be accurately characterized as a symbiotic relationship between conversants, each of whom has the capacity to shape the conversation. ${ }^{32}$ This kind of research can be conceived as a collaborative "process of sense-making" in which all those involved are part of a larger "information economy" that none of them controls. ${ }^{33}$

To understand field research as anything other than a symbiotic back-and-forth is to misrepresent it and undermine our informants' autonomy. The power dynamics between researchers and researched are especially complicated in conflict zones, where violence is a key currency in all relations. There is a persistent "potential for danger" that comes with research in the midst of violence. ${ }^{34}$ Situations arise in which a fieldworker is unable to control her interactions with her informants. Even research with youth, when they are armed and streetwise, can lead to "a dramatic shift in power." The notion that the researcher has control over this context is simply out of alignment with facts on the ground. A researcher can actually be much more dependent on her informant than the informant is on her. ${ }^{35}$

Power asymmetries can be particularly pronounced in research with elites, especially those with outsized access to coercion and capital. As young graduate students, we had little reason to believe that we would command power over well-established, political and military elites. Field research can sometimes mandate a 'guest' and 'host' relationship that upends the presumed 'investigator-subject' paradigm 
entirely. Laura Adams, writing about her work in Uzbekistan, explained, "the guest dynamic plays a trick in which the apparent power relations are inverted ... When a fieldworker accepts the guest contract, she trades a measure of freedom for a measure of protection. ${ }^{36}$ During a trip to Afghanistan, one of us found herself invited to dinner at the home of a former militia commander. She had not expected an interview to parlay into a gathering of former mujahideen. Although the conversation proved fruitful for her research, one could hardly characterize her as the more powerful party vis-à-vis her informants. On the contrary, she was a guest whose research aims, reputation, even safety were in the hands of her hosts.

Researchers are not exempt, in these contexts, from becoming political resources to their research subjects, especially when political elites are the subjects of concern and elite interviews serve as a central research instrument. A handshake one of us shared with an Afghan governor he had met with for less than five minutes was broadcast on local television. This appeared to be a concerted attempt to counteract the governor's reputation as an uneducated countryman by exhibiting his connection to a foreign university professor. In another instance, the same author was mentioned in a public speech by a warlord's lieutenant as evidence of the international community's interest in his liege. A researcher can become, wittingly or unwittingly, "an important element in [a research subject's] strategies to attain certain objectives." 37 Eva Gerharz, for example, described how researchers operating in Sri Lanka were used as "potential promoters and sometimes even advocates by the [Liberation Tigers of Tamil Eelam]." ${ }^{38}$ A power dynamic of this kind can, in its extreme form, result in the researcher becoming a "mascot," utilized by locals to advance their interests. 39

The reversal of the conventional power paradigm occurs in a variety of contexts. Experimentalists can, for example, be instrumentalized by individuals who leverage their knowledge of the local political landscape to influence selection processes for the benefit of their communities. Perhaps more problematic is the manipulating power that fixers, interlocutors, and informants can have over knowledge production by vengefully pointing fingers at people who have wronged them (and who are not covered by the human subjects protection guidelines). ${ }^{40}$ This is particularly concerning because, as Driscoll put it, "set[ting] in motion those downstream consequences is often the reason that people are talking to us in the first place." 41

These ambiguities have striking resonance with other forms of intervention. Peace-builders, state-builders, and counterinsurgents often believe that they have the authority, responsibility, and capability to transform societies plagued by violent conflict, authoritarian politics, and socioeconomic underdevelopment. ${ }^{42}$ The perceived transformative authority resides within a system of "organized hypocrisy" in which the most powerful states respect the sovereignty of weaker states only so long as it remains in their interest to do so; ${ }^{43}$ the "responsibility to protect" suggests that the sovereignty of these states is contingent on good behavior. ${ }^{44}$ The international community's perceived transformative capability lies within a "conceptualisation of modernisation ... as a project of social engineering." ${ }^{45}$ These beliefs about the power of the outsider are grounded in some undeniable realities, but also in perceptions that are grossly exaggerated. ${ }^{46}$

In fact, local actors have long instrumentalized the presence of foreigners in conflict zones. ${ }^{47}$ Since 2001, Afghan notables have leveraged the presence of Coalition forces to their own ends. They have, for example, exploited the Western eagerness to hunt the Taliban to advance their own interests and settle personal feuds. ${ }^{48}$ In war zones, more generally, local elites bargain with one another over power and loyalty, often through the use of force, while foreign players remain largely disadvantaged outsiders, "readily manipulated or bypassed by the better-endowed and cannier national players." ${ }^{49}$

In sum, interveners, scholarly or otherwise, are engaged in power relationships that are far from unidirectional. Westerners may represent, even wield, great power within the international system and still be unable to define events at the micro-level. It is possible, in other words, to intervene and still be vulnerable to forces beyond one's control. ${ }^{50}$ Like any other outsider, a researcher can become an object of manipulation by parties to the conflict she studies. Foreign researchers have access to specific resources that sometimes place them in a position of power. Yet, informants also have access to resources of their own, including their superior understanding and knowledge of all that is 'local.' They are in a position to leverage the presence of foreigners to ends often beyond their knowledge, let alone their control.

\section{On (Im)Partiality}

The fact that the researcher's dominance over her subject cannot be presumed has implications for how researchers comport themselves. There are steps they might take because of the limited power they have that do not align with another related and long-held fieldwork precept- the aspiration to be "the fair ethnographer." 51 Impartiality, sometimes framed as objectivity, has been historically understood as a prerequisite for rigorous fieldwork. ${ }^{52}$ As Robert Keohane urged, "in our particular investigations we need to seek objectivity because otherwise people with other preferences will have no reason to take our findings seriously." ${ }^{53}$ Relatedly, it was almost axiomatic that a scholar should remain neutral and independent. ${ }^{54}$

This commitment to a position of impartiality, neutrality, and independence is captured by the "fly-on-thewall model," namely "the idea of a value-neutral, unbiased, 
and minimally disruptive social science." In this ideal type, the researcher "takes pains not to express opinions, take sides, or draw attention." ${ }^{55} \mathrm{We}$ add our voices to the chorus of scholars who question the implications of this commitment by drawing attention to the unviability of such a posture in the midst of violent conflict. As Jonathan Goodhand warned, "research, like any other form of intervention, occurs within an intensely political environment and is unlikely to be viewed by local actors as neutral or altruistic. ${ }^{" 56}$ In highly charged environments, partisanship of some sort may become unavoidable $;{ }^{57}$ it might even be a security imperative. ${ }^{58}$

We start by considering neutrality, because it is the one dimension of this posture in which the scholar has the greatest volition. Today, some in the academy "feel a special obligation to ... speak up for those trapped... in repressive political environments. ${ }^{\text {" } 99}$ Others seek to leverage their knowledge to influence Western policymaking. Activist research involves an agenda to improve the conditions being studied. ${ }^{60}$ Michael Mosser encouraged social scientists to foster the "'revolving door' between the academy and the policy world," in particular the military and defense establishment. ${ }^{61}$ Charli Carpenter and Michael McCann acknowledged their (sometimes unintended) roles as changemakers in the arenas they studied, international human rights and American labor rights respectively. ${ }^{62}$ And Lara Deeb and Jessica Winegar pondered why anthropologists, as a community, did not strongly protest "the horrors of escalating Islamophobia ... and the unleashing of the world's most powerful military on Afghanistan and Iraq." 63

Scholars of an activist persuasion might advance an obligation to study charged subjects like Afghan warlords in a way that acknowledges, even works against, the harm inflicted on those living under their reign. In one awkward conversation, one of us was asked by an international organization official to share any information on militias that could help "give justice to the people." This was a difficult position: either betray the trust of future informants or go back on a tacit understanding that the official had imposed. Our decisions to abstain from moralizing about our research subjects have earned us critique from onlookers on multiple occasions.

But, in addition to the intellectual reasons for avoiding normative claim-making, trying to 'do the right thing' can have far-reaching consequences. For example, William Reno was menaced by former warlord and President of Liberia Charles Taylor himself after testifying before the U.S. Congress. "It was the first wake-up call," Reno remarked. "Things that you did in the past have downstream applications ... [they] can come back and they can haunt you. ${ }^{" 64}$ In a case like this, a researcher's efforts at advocacy can jeopardize professional and physical integrity. The emergence of international criminal law and the existence of a criminal court that claims universal jurisdiction have further consequences. Fieldworkers who gather rich empirical data on armed actors now run the risk of being called to testify as expert witnesses, or even of being subpoenaed to release their data. ${ }^{65}$ This legal and normative shift may take away the researcher's choice to remain neutral altogether.

Beyond the ethics (and risks) of actively taking sides, many have come to wonder whether a truly impartialobjective and unbiased-approach has ever been genuinely tenable. After all, undertaking research often has social, political, and economic implications; moreover, the researcher can never control how her acts are perceived. ${ }^{66}$ A rich body of literature has arisen around the fallacy of impartiality as a cornerstone of social science. ${ }^{67}$ Every researcher has a host of different identities that shape the dynamics of interaction with research subjects. ${ }^{68}$ As Charli Carpenter explained: "My various identities-American, political scientist, professor, woman, mother-were interpreted differently in different research contexts and always affected the data I was able to gather." ${ }^{\text {69 }}$

With some methods, like participant observation, the process of immersion into a community may make working at any remove impossible. ${ }^{70}$ Similarly, in some contexts, an immutable feature of a given researchera Jewish Israeli studying the Arab-Israeli conflict, for example-may make it impossible for a scholar to be perceived as impartial. ${ }^{71}$ Some scholars may wish to cling to their identities as genuinely disinterested observers. They do not wish for their curiosity to be confused with admiration. ${ }^{72}$ And, yet, one's aspiration to acquire knowledge may be read as support by others. In Sri Lanka, Gerharz found herself perceived as "being more sympathetic to the "terrorists," because she suggested federalism as a sustainable solution to the conflict. ${ }^{73}$ Similarly, onlookers might have assumed an affinity between each of us and a given Afghan warlord we had chosen to investigate. This was a challenging affiliation to manage and one that became hard to shake after years of research. Throwaway remarks like, "your friend, the governor" indicated that the study of a controversial figure could quickly be conflated with sympathy for, even complicity in, that individual's political project.

Researchers can also be identified as confederates to the policies of their governments. During field trips to the Turkish-Syrian border, one of us was confronted by anger about the U.S. government's response to the Syrian civil war. On occasion, an interview devolved into an interrogation by the researched about American foreign policy, President Assad, and Syria's fate. Assumptions about the opinions of a given researcher may be coupled with a more general belief that Western academics have the power to influence 'the establishment' back home.

These assumptions can be harmful, as being associated with a government's domestic or foreign policies a fortiori, can put a researcher at risk. Scholars deploying various 
methods have been forced to contend with this reality. The act of, for example, undertaking a survey can be perceived as a partisan one. Arab-American scholar Amaney Jamal, conducting survey research in the Palestinian territories, found herself suspected of affiliation with the Palestinian National Authority. ${ }^{74}$ In a field experiment in Lebanon, Daniel Corstange found that respondents were far less likely to take a survey they were told was sponsored by a Western government than one in which no mention of sponsorship was made. Although sponsorship by an American university did not dampen participation, for qualitative researchers who engage communities in less formal terms, distinctions between 'governmental' and 'academic' are not always easily broadcast. ${ }^{75}$

In Afghanistan (and Iraq), the risk of association was aggravated by the now-defunct "Human Terrain System," a program aimed at embedding social scientists within the U.S. military to provide "socio-cultural knowledge of the indigenous civilian population." ${ }^{.76}$ This program further blurred the line between soldier, spy, and researcher and may have exacerbated perceived associations between them. The line between research motivated by policy versus scholarly interest may be difficult for observers to decipher. This is particularly true if, as Dawn Langan Teele suggests, researchers "are increasingly engaged in bringing policy ideas to governments and think tanks to be tried out in real-world settings." 77 We, ourselves, have received government funding, published articles with think tanks, and worked as consultants for both. These engagements do not connote our endorsements of the policies of these patrons, but they preclude us from dissociating ourselves entirely from them. To be fair, objective, balanced, and perceived as such in this context is nearly impossible. ${ }^{78}$

Moreover, today's Western scholar, like the journalist or aid worker, can be an "object of interest" in her own right. ${ }^{79}$ In the latest generation of "new wars," marked by acute Western involvement (particularly those in the "greater" Middle East), militant organizations seem to make little distinction between different Westerners. This development might be dated back to the mid-1990s when, as Fawaz Gerges explained it, "The jihadi caravan took a new sharp and dangerous turn that [brought] it into a total confrontation with the world community." ${ }^{" 80}$ The growing conflation of a larger struggle - the "global jihad against the West" ${ }^{\prime 1}$ - and a number of smaller-scale conflicts made Westerners working in their midst vulnerable in unprecedented ways. ${ }^{82}$

The researcher's inability to be (and be recognized as) impartial raises concerns about a third aspect of her position-her independence. It is impossible, in these circumstances, to be truly independent absent a far greater degree of power than most social scientists have. Westerners have become lucrative prey for kidnapping as well as attractive targets of lethal violence in unconventional military campaigns. As such, work in hot conflict zones might demand protection from powerful local or foreign actors with whom one would prefer not to affiliate. While working in Mogadishu, for example, one of us benefited from the informal protection of an African state's diplomatic office as well as from a warlord once backed by the CIA. The other took advantage of U.S. governmentsponsored flights in Afghanistan to avoid the dangers of travel by road, even spending a few days on two Western military bases. To need help is to acknowledge the limits of one's power.

Here again, an analog exists: the desire of humanitarian aid agencies to maintain the sacrosanct values of impartiality, neutrality, and independence. ${ }^{83}$ In the last two decades, organizations that took pride and solace in their ability to operate above the fray perceived a shift whereby that ability could no longer be assumed, partly as a result of the militarization of humanitarian assistance. ${ }^{84}$ Since 2001, many terrifying episodes have revealed the degree to which Western organizations no longer feel protected by the cloak of impartiality, neutrality, and independence. $^{85}$

While some have argued on behalf of "returning to traditional principles, $" 86$ others posit that the presumption that "humanitarian action is not a political project" is a dangerous one. It "rings," wrote Paul O'Brien, from CARE Afghanistan, in 2004, "like an honorable lament for the past, but no longer provides adequate guidance to humanitarian actors in highly politicized settings." ${ }^{\text {" }}$ O'Brien's warning is one, we would argue, to which field researchers should also pay heed. Scholars have indeed been forced to ask many of the same questions our humanitarian counterparts have been asking themselves:

Are aid organizations irrevocably intertwined with the U.S. and Western agenda in the minds of violent opponents and, even more alarmingly, of the local population? Are the fundamental principles that have typically characterized and guided humanitarian action, in particular impartiality, neutrality, and independence, still valid in such crises? Do aid organizations have choices left other than to seek armed protection and to work in full cooperation with Western military and political forces or to simply retreat ${ }^{88}$

Honest answers would reflect the reality that $21^{\text {st }}$ century interveners, including scholars, are part of the social, political, and economic equations that comprise life in these warzones; and they do not have the power to float above the fray with the aloofness they may have heretofore.

A field researcher routinely engages in a delicate dance with her subjects, striving to signal her role as listener, not partisan or judge. Still, there is little reason to believe that scholars are immune from the taint of unwanted affiliation or that they can operate independently in today's conflict zones. We would assert that those working in particularly challenging environments have little choice but to confront their limited power and vanishing impartiality, and, therefore, independence. Those who 
pursue qualitative fieldwork with elites in today's warzones are in fact engaged in a kind of tribal politics of their own.

\section{Field Research as Tribal Politics The Method of Building a Tribe}

The optimism of those who believe fieldwork in war zones is possible hinges, in part, on the notion that "investing in a local network" is the antidote to many of the challenges at hand. ${ }^{89}$ As Reno said: "You have to become part of the system to study the system." ${ }^{\text {"90 }}$ In the places we study, this means belonging to one or more tribes, micro-systems of networks and individuals who recognize themselves as linked to one another and can offer a researcher access, support, and protection. ${ }^{91}$

Innate or imagined, ${ }^{92}$ tribal affiliations remain a defining feature of politics in what Jean-Francois Bayart called "rhizome state[s]," with their "infinitely variable multiplicity of networks whose underground branches join together the scattered points of society." ${ }^{93}$ The focus of our own scholarship involves an examination of tribal politics in the broadest sense of the term - we study statesociety relations marked by informal, patrimonial, and patronage-based institutions. These variants of political life are highly diverse in form, but there are commonalities: Personalized relationships are ubiquitous, rules are often informal, and information is of very high value, often hidden or hard to find. Outsiders are challenged navigating these systems, elevating the importance of brokers and go-betweens. $^{94}$

These features affect not only the politics they produce, but also the ways in which students of those politics pursue knowledge and construct meanings about them. The features that distinguish tribal politics from other brands are determinative of the kind of research that can be done in their midst. We see snowball sampling as the methodological correlate to engaging in tribal politics, a way of grafting oneself on to one or more of Bayart's networks of "underground branches." N. Patrick Peritore described this approach as "respondent pyramiding," whereby one builds a network of informants, one on top of the other. ${ }^{95}$ In this sense, the method we use mirrors the politics itself.

Snowball sampling, a method very popular amongst scholars of the Middle East, ${ }^{96}$ offers opportunities to address the trust deficit inherent in war zones, ${ }^{97}$ where informants tend to be suspicious of newcomers. ${ }^{98}$ The building of embryonic "trust networks" is in fact an absolute necessity, ${ }^{99}$ as informants are more likely to share information with those they have come to know and trust. ${ }^{100}$ Snowball sampling can therefore be understood as a form of social infiltration into an impervious setting in which the proper introduction can get a researcher a long way. ${ }^{101}$ In these environments, "the goodwill of. . .gatekeepers among power elites is often essential to be able to begin, pursue, and complete research."102
There is also a more human reason for cultivating trust with one's informants. Students of war find themselves in foreign, frightening places where connection is not only a vehicle for knowledge acquisition, but also for the alleviation of their own fear. Anxiety shapes the field experience, much as theoretical knowledge, access, and analytical acuity do. ${ }^{103}$ Scholars are not immune to posttraumatic stress disorder (PTSD) and, more generally, to the psychological impact of this work, in the field and thereafter. There is a danger that they adopt the comforting but inaccurate belief that violence is "symptomatic of some social pathogen that is to be circumvented while maneuvering about the field" when, in fact, it is at the heart of their experiences. ${ }^{104}$

Amidst such insecurity, the researcher's "friendship group" becomes her "safety net." 105 In keeping with the "friendly" images social scientists wish to have of themselves, ${ }^{106}$ they pursue relationships, in part for the genuine sense of trust they afford. Trust is the currency by which fear can be overcome, entry facilitated, and relationships built. At times, successful tribe-building on the researcher's part may not only compensate for relative weakness, but may actually establish a new balance of power in her favor. After all, the development of dense connections can mean access to information, key stakeholders, protection, and understanding in ways that enhance a researcher's capacity to operate within her surroundings.

The metaphor of tribe is especially apt, because the kin-based quality of tribal affiliations makes them stickier than more volitional relationships. As the saying goes, 'you can't choose your family,' and the same goes for the tribe. The tribe is a collective, in which an individual can access a kind of strength and protection she otherwise could not; but that individual, especially a newcomer, will never be in full control of her position within the larger system nor can she pretend these bonds are without their own politics. There is a deterministic quality to tribal relations, because they are anchored in kinship: who you are will meaningfully dictate with whom you will connect. Field sites are not free, open markets for the trading of allegiances; instead, agency is limited. In the midst of contentious politics, a researcher may be unable to move as she pleases from one network to the next; and previous affiliations will shape her path going forward. In this sense, the concept of tribe reflects the limits on a researcher's power and impartiality.

In Afghanistan, Somalia, and southern Turkey, we have adopted our own brands of tribal politics, incrementally joining, exiting, and returning to various, sometimes overlapping, networks to build our own tribes. While the range of networks to choose from may be less predetermined for us than for those we study, who we are and how we are perceived by others still greatly influence our tribe-building efforts. Nationality and ethnicity may have been two of our most obvious tribal markers. One of 
us, of Indian descent, consistently received a warm reception amongst Afghans, many of whom expressed affinity for India, its culture, and people; perhaps the widespread antipathy for the Pakistani government found in both Afghan and Indian societies was also a factor. The other likely penetrated northern Panjshiri networks in Afghanistan more easily by virtue of being French. The pre-existing relationships between members of the 'French tribe' and Panjshiri commanders-who received support from the French government and NGOs during and after the Soviet-Afghan war-greatly helped him in gaining entry and intimacy. In both cases, these associations facilitated understanding, access, and hospitality, making these identities an undeniable variable in the tribebuilding equation.

A scholar's reputation and actions ("on" and "off-duty") are also key to being admitted and remaining in different tribes. ${ }^{107}$ Researchers can attract attention in ways that make them uncomfortable or that they fail to recognize altogether. As Stephen Brown noted, "the separation of the public and the private is a fiction that is hard to maintain in most research sites." This, we would argue, is especially true in societies marked by tribal politics. One's gender, sexuality, marital status, personality, and opinions all shape the experience of being an "object of interest." 108 One of us learned early on, as a female researcher, to be particularly cautious about her relationships with male counterparts. ${ }^{109}$ The "intersection" of her gender identity with her perceived nationality, "Indian," may have further complicated expectations about how she should behave. Perhaps she was expected "to play by the rules" that applied to South Asian women? ${ }^{110}$ Her ethnic background likely opened some doors, but a failure to comport with associated expectations may have threatened that access.

In any number of ways, then, our otherwise very similar scholarly experiences-as two junior scholars studying warlordism in post-2001 Afghanistan-were quite different from one another. Our different nationalities, genders, and personalities ${ }^{111}$ shaped the trajectories of our research when it came to access, mobility, and protection. And our experiences thereafter, in Somalia and Turkey, were distinct from those we had forged in Afghanistan, as we worked to build new tribes in very different societies.

The notion of 'building a tribe' has, once again, a number of analogs in Western intervention. Imperial practices in the Middle East, for example, involved the cultivation of close relationships with tribal leaders. T.E. Lawrence explained how he was "sent to these Arabs as a stranger, unable to think their thoughts or subscribe their beliefs, but charged by duty to lead them forward and to develop to the highest any movement of theirs profitable to England in her war." ${ }^{112}$ Tribal engagement has been resurrected in the $21^{\text {st }}$ century as a sometimes celebrated, often controversial instrument of statecraft and uncon- ventional warfare. ${ }^{113}$ But, from the "Anbar Awakening" campaign in Iraq to the Shinwari tribal pact in Afghanistan, many argue that Western efforts at building tribes come with real risks. ${ }^{114}$

And, yet, we have come to realize that, operating in a hostile environment in which our positions are ones of limited power, we have had little choice but to undertake our own smaller versions of tribal politics to succeed and, sometimes, survive. Of course, our tribe-building does not involve coercion and capital of the kinds characteristic of military intervention, nor are our motives strategic or ideological. Nonetheless, it would be foolhardy to assume that they can be universally interpreted as apolitical.

\section{The Risks that Come with Being 'All in the Family'}

While joining and building a tribe may at times be necessary to conduct research in hot conflict zones, it also involves dangers. What was true for Philippe Bourgois twenty-five years ago - "we are outsiders...we have a formidable capacity unwittingly by our mere presence to cause trouble or to seriously complicate matters"remains true today. ${ }^{115}$ To start, joining a tribe implies embracing, knowingly or otherwise, its existing friendships and enmities. The researcher can become a target of violence or get caught in the crossfire. The base in Afghanistan on which one of us spent a few days was attacked years later, while the Mogadishu hotel in which the other stayed also came under assault. The Somali warlord who had provided protection (the owner) was killed, as were a dozen hotel guests.

Tribes can also involve a tacit degree of reciprocity and a set of obligations to the researcher's new 'family.' In warzones, this can become ethically dubious ${ }^{116}$ and dangerous. "You have to fight for us now," a Somali warlord hosting Reno jokingly told him after his men were targeted in a suicide bombing. "In the back of your mind," said Reno, "you know your relationship is not like staying in a hotel. The guest belongs to the host." 117 This problem is magnified by post-9/11 U.S. legislation prohibiting the provision of "material support" to "terrorist groups." Tribe-building may now have grave legal implications for those studying armed groups. The notion that communication with a designated terrorist organization could be construed as illicit support introduces an "inevitable chill on much-needed scholarship." 118

There are also risks researchers impose on those within their networks. These are further aggravated by the relative lack of anonymity both within the tribe-where "interviewees either know or can trace each other" ${ }^{119}$ —and outside the tribe, as foreigners tend to "[draw] attention to those in their orbit." ${ }^{\prime 20}$ In one very uncomfortable situation with Afghanistan's second vice president, one of us was asked whom he had met prior to this visit. He could do nothing but witness his interpreter divulge the names of the people 
interviewed earlier that day. Although this episode had no further consequences, it points to the lack of anonymity and the "dilemmas of proximity" ${ }^{21}$ that can result from being 'all in the family.' Researchers also have little to no control over the life and career paths of their fellow tribesmen once their times together draw to an end: Interpreters, fixers, friends, and informants may rise in prominence and become players in the systems they were hired to study. Their decisions about what information to share and with whom may have unforeseen consequences as well.

There is also the concern of betrayal by the scholar-real or perceived-and the possibility that, once work is published, informants will learn of and be angered by the interpretations put forth. ${ }^{122}$ For participant-observers, this risk exists from the start, as researchers toggle between the identities of "a 'good friend' and a 'snooping stranger." ${ }^{123}$ But, to varying degrees, this is a concern for all field researchers ${ }^{124}$ that lies at the heart of what is almost always an exchange based on "partial trust." 125 As Fine mused, "the illusion of being more sympathetic than we are aids research but is deceptive. . Our informants have given us a 'gift,' but how have we returned the favor?" ${ }^{26}$ Also problematic is the question of what a scholar owes "repellent" subjects in terms of not harming their reputations. ${ }^{127}$ The simple act of describing an Afghan leader as a 'warlord' could create irreversible tension with informants in his circle. Militia commanders, opposition leaders, business tycoons, and government officials are not invulnerable to exposure and critique. On the contrary, their power rests, at least in part, on their ability to project credible authority.

The possibility of piquing one's research subjects can also have implications for one's ability to return. Scholarly work can now be accessed in just about every corner of the world by anyone with an Internet connection. As a function of technological innovations, the residue of interactions between researchers and their informants, fixers, interpreters, and hosts is stickier than ever before. Mobile phones, email, virtual libraries and bookstores, online newspapers and magazines, think tank websites, social networking platforms, and so on make it difficult to 'exit' the field. Researchers now have "digital profiles." 128 The days are long gone when research "was done in remote areas where there was little possibility of reports of findings coming to the attention of those studied." ${ }^{29}$

There is, of course, the reverse risk: Bias inevitably creeps in as one comes to know and even like the people one is studying. As detailed above, true objectivity is an illusion, but researchers must be aware of the degree to which they are at risk of losing it altogether. ${ }^{130}$ Scholars experience fieldwork, not only through rational observation and analysis, but also through sentimental reactions that can shape their conclusions. ${ }^{131}$ Profound biases may be insurmountable if a researcher only interacts with those within "the specific network being accessed."132
Researchers can, inadvertently, take sides in surrounding power struggles in ways that block them from establishing links with others or put them at risk. ${ }^{133}$ Alice Goffman, who spent years in a tough West Philadelphia neighborhood, admitted her "desire for vengeance" after one of her friends (and research subjects), was murdered-she drove herself and a friend (and research subject) around in search of the killer. ${ }^{134}$ Tessa Diphoorn witnessed a vicious attack perpetrated by members of a South African private security team within which she was embedded. She wondered if her role as "audience" "influenced their performance of violence ... and triggered a particular type of macho behavior."135

Scholars must acknowledge their own emotional reactions as part of the research experience, including moments when they find themselves paralyzed, excited, or even sympathetic in the face of violence or power. ${ }^{136}$ Antonius Robben found himself taken in by alleged Argentine war criminals, whose reputations did not comport with their "great civility... considerable knowledge of literature, art, and classical music. . . [and] affability and chivalry." He described this discomfiting phenomenon as "ethnographic seduction." 137

One of us, after meeting with a famed warlord, reported: "He has a very unique way of looking into someone's eyes. His tiny half-closed eyes seem to see right through your soul." ${ }^{38}$ This 'celebritization' of the research subject is a reflection of the real and perceived power armed actors can impress upon others. This was, in fact, an important dimension of our own research about them. And, yet, as visitors to their lavish palaces, we felt intimidated and excited by proximity to such blatant manifestations of power. We were also disarmed by the adeptness with which these strongmen engaged us. Seducers (conscious or otherwise) come in the form, not only of the bogeymen of violent conflict, but also civil society leaders and even victims of violence. ${ }^{139}$

Another, related risk, for the researcher, is the delusion of belonging when, in fact, she can never become a true insider. She may borrow and learn from the tribe she joins, but will never belong in the same way her native counterparts do. ${ }^{140}$ Social media networks can be useful modern tribe-building tools, but they further this delusion. On the one hand, they allow researchers to maintain relationships with informants and research subjects; ${ }^{141}$ they also open the door to a new kind of data collection about violent political actors living in secluded areas (Islamic State militants in Iraq and Syria, for example). ${ }^{142}$ On the other hand, building a virtual tribe through social media can impute a false sense of kinshipFacebook "friends" are not necessarily real friends; it also introduces "the danger of becoming too publicly or privately friendly with sources, at the risk of giving them a higher profile or being perceived as validating their views." 143 
The sense of belonging also carries with it a misplaced sense of knowing that has real implications for the researcher's thinking, analysis, even safety:

We no longer seek to grasp the native's point of view, but we believe, at least for the duration of the meeting, that we have become natives ourselves...that we have accomplished something profound in the encounter, that we have reached a deeper understanding and have somehow penetrated reality. ${ }^{144}$

Many researchers have experienced this 'eureka!' moment. Only after the encounter does it become clear that their emotional experience has betrayed their humility as analysts. ${ }^{145}$ Such encounters can represent one of the great thrills of fieldwork and need not necessarily signify a failure to understand or learn. But they do represent a risk implicit in the tribe-building endeavor.

\section{Back to the Verandah?}

Given the challenges involved in tribe-building, one has to wonder whether field research in dangerous places is advisable anymore. Western scholars cannot operate under the assumption that they will be recognized simply as observers cataloging events. Instead, they have become players, even potential targets for blanket forms of antagonism.

\section{Innovating from a Distance}

Today, little field research is being done in particularly violent war-torn regions such as Syria and southern Somalia, where the security conditions severely limit access to relevant populations. ${ }^{146}$ Still, many researchers continue to venture into the hinterlands of conflicted countries to establish their credibility as experts with 'ground truth.' But even they must revisit their thinking about the conduct of this kind of research. In the most dangerous settings, some restrict themselves to conducting interviews in the country capital, while others limit themselves even further, inviting informants to meet at a few designated 'safe' places. Others may hire local researchers to conduct interviews and surveys on their behalf. Interviews in country capitals can be extremely informative, while collaboration with local researchers can add great depth to inquiries previously pursued only by outsiders.

New technological tools also afford researchers insights into places from which they are otherwise excluded. Jacob Shapiro and Nils Weidmann employed data about Iraqi mobile phone network coverage to investigate the impact of "improved communication" on "the rise or fall of violence during insurgencies." ${ }^{147}$ David Mansfield combined rich fieldwork with geospatial imagery to study poppy cultivation in Afghanistan. ${ }^{148}$ Alexander De Juan and Andre Bank utilized satellite imagery to measure the provision of electricity in regime-controlled territories within Syria alongside crowdsourced accounts of warrelated fatalities to establish patterns of violence. ${ }^{149}$
These are innovative approaches that enrich data collection; however, if they are used exclusively, they can introduce a space between researcher and researched. If so, they become reminiscent of the "verandah model" of ethnography, with "the field-worker, sitting on the verandah of the government station, sending for a 'native' who will be subjected to several hours of systematic questioning about his ... language and customs." Joan Cassell characterized this approach as "historically obsolete," but we would argue that versions of it will grow more prevalent as conflict zones become increasingly inhospitable to Westerners. ${ }^{150}$

Here there are clear parallels to intervening actors once again-international aid, development, and diplomatic organizations-whose efforts in the field have been critiqued because of the way they operate in war zones. ${ }^{151}$ Seclusion, albeit often reluctant, has been a hallmark of the aid worker's life in $21^{\text {st }}$-century warzones. This is increasingly the case in cities like Kabul where violence against foreigners has become more norm than aberration. Foreign researchers are by no means immune from this trend. In 2014, two scholars teaching at the American University of Afghanistan were killed in an attack on a popular restaurant in Kabul; in 2015, a researcher was killed on a visit to Kabul in an attack on her hotel; and, this year, two more researchers associated with the American University were kidnapped in Kabul, and the university campus came under assault, resulting in over a dozen deaths.

The analog between research intervention and aid intervention is acutely evident in Syria and Somalia. One of us set out to study the Syrian conflict from within Syria in 2013 but, on account of the deteriorating security situation, had little choice but to work from within southern Turkey. Similarly, Western donor organizations were forced to understand politics, forge relationships, and deliver aid from over the border. Those studying southern Somalia must operate primarily from Kenya or Somaliland, much like their NGO counterparts. The view "from the verandah" can give scholars leverage on certain subjects—like displacement, diaspora relations, and regional geopolitics-but interviews outside the conflict 'theater' have their own problems (sample representativeness, to name one).

Moreover, researchers (and their intervening counterparts) cannot rest easy that 'safe' places, proximate to but removed from conflict, will always remain so. The security situation in cities along the Turkish-Syrian border can no longer be taken for granted; this year, a massive suicidebombing shook the town (and research site) of Gaziantep. The larger political climate in Turkey is also cause for concern. Turkish President Erdogan has singled out academics-local and foreign-for their critique of his government. It bears remembering that the pursuit of field research has proved challenging, not only in countries in 
conflict, but also in those with "hybrid regimes," such as Vladimir Putin's Russia or Saddam Hussein's Iraq. ${ }^{152}$

\section{Keeping Our Feet in the Field}

Since the U.S. wars in Afghanistan and Iraq, Westerners of all stripes have become targets of violence in largely unprecedented terms. In these conditions, scholars of $21^{\text {st }}$-century warfare may need to reacquaint themselves with the verandah, but many are not yet prepared to forsake the field. We argue that this kind of fieldwork can still be pursued but only if researchers acknowledge and engage with their positionalities in the face of violent conflict. Researchers may have no choice but to build tribes of their own. There are a host of risks-physical, psychological, analytical, even legal-that accompany this endeavor, but they are not necessarily insurmountable. Here, we identify three ways of mitigating against them. We do not claim that these are the only ways to deal with deteriorating conditions or that they are foolproof; instead, we simply offer insights from our own experiences.

Rethinking Tempo While there are obvious advantages to staying in one's field site for months, or years, at a time, there are also disadvantages. The well-integrated researcher becomes a resident fixture on the local scene, enmeshedor at least perceived as such-in particular networks and communities. A more economical approach to fieldwork, while vulnerable to a number of deficiencies, affords a greater remove. We made multiple trips for months, weeks, even days at a time, which allowed us to enter and exit on our own terms. We built trust through repeated encounters over several years with a wide range of individuals, including those who had poor or no relationships with one another. Time between trips enabled us to construct a more deliberately balanced panel of informants.

Finding Strength in Weakness One of our core claims is that researchers ought not to assume themselves to be the more powerful actors in the 'researcher-researched' dyad. Yet, there are some advantages researchers can leverage as a function of their youth, gender, or ethnicity even when those traits are associated with relative weakness. As a female, one of us could not avail herself of the 'hanging out' that her male co-author enjoyed, like playing cards with former commanders far into the night. But she had little trouble securing interviews; perhaps local elites were disarmed by the element of surprise when confronted by a novel and non-threatening profile. And the formality that marked most of her encounters allowed for a strategic distance that kept things less complicated.

Our limited resources also represented a weakness but, in fact, may have made us more secure. In Afghanistan, we did not have the budgets to hire security, travel in bulletproof SUVs, or stay in well-appointed hotels.
We operated, instead, with very low profiles: absent an entourage, unarmed, and with inconspicuous vehicles and lodging that did not draw attention. Paradoxically, an under-resourced presence afforded us the opportunity to find some security by remaining at least somewhat under the radar.

Embracing the Symbiosis Most importantly, we acknowledge our limitations as outsiders and embrace a collaborative approach that accommodates them. We welcome J. Christopher Kovats-Bernat's notion of a "localized ethic," whereby all those involved in the research share in the responsibility and risk. ${ }^{153}$ We have deferred to our interpreters, fixers, hosts, friends, even drivers about how to engage substantively as well as logistically_to pursue or not pursue a certain interview; to ask or not ask a specific question; to go or not go to a particular place; to wear or not wear a particular veil. While some scholars have suggested that a researcher can avoid dangerous conversations altogether, ${ }^{154}$ there will be times when a researcher cannot predict which questions (and answers) will introduce risk. We, too, preference the notion that people in their own communities are "certainly better at anticipating danger...over any arrogant presumptions as to what [is] supposed to be best for them."155

A symbiotic approach to fieldwork can extend beyond a researcher's engagement with her interpreters and informants. One of us adopted a new approach for a recent project, working with an Afghan team to gather data after completing her interview-based research in Kabul. This hybrid approach combined the expertise of a foreign scholar with the knowledge and access of local researchers, producing an arguably superior outcome than could have been achieved by either party alone. Although collaboration raises certain risks - physical, ethical, and methodological ${ }^{156}$ —a "localized ethic" may be more viable today than ever before.

\section{Here an Intervener, There an Intervener, Everywhere an Intervener}

A great deal of research on contemporary conflict has produced critiques of intervening actors, calling their power and purpose into question. Interveners can no longer pretend they are omnipotent and impartial. We would argue that the scholars who study these interveners must recognize themselves as guilty of some of the same sins. At the same time, fieldworkers have developed skills to adapt to this changing environment, because they must to pursue the knowledge they seek. This adaptation comes with risks but also opportunities for innovation and collaboration. Ultimately, the fate of fieldwork in warzones rests on a recognition that research is a form of intervention in which scholars build their own tribes, with all the risks and pitfalls that such a project involves. This reality should be acknowledged -by professors, editors, funders, and Institutional Review 
Boards alike ${ }^{157}$, not least because these scholars often carry on important research agendas that could not be pursued otherwise.

Jeffrey Isaac recently critiqued what he called "a resurgent neo-positivism" with its focus on "methodological hyper-sensitivity, 'scientific rigor,' and expert authority." The veneration of positivist ideals means that "every piece of research [should be] purged of partiality and oriented toward achieving an accurate representation of reality that anyone else, anywhere, can potentially 'replicate' and assess." ${ }^{158}$ Field experimentalists, for example, are working to mimic lab-like conditions in some of the same settings where their qualitative counterparts are working, but with assumptions about power and impartiality that are quite different from the ones we posit here. And yet, the degree to which they are "intentionally manipulating the research environment" might make their work even more intervention-like (and disruptive) than ours. ${ }^{159}$

Here our purpose is not to single out experimental work, but to suggest that conversations about power and (im)partiality should be and are being had amongst political scientists of different methodological persuasions. ${ }^{160}$ Ideally they need to take place across methodological fault lines, including amongst those working within the increasingly challenging conditions of war-afflicted research sites. We join the call to acknowledge the roles political scientists play in the construction of knowledge, in particular that their lack of omnipotence and remove obviates the possibility of 'scientific' impartiality. As Marie-Joëlle Zahar put it: "not only is objectivity an ideal, it might actually be a false god." 161

Our use of the metaphor of tribal politics, while imperfect, is meant to underscore that who we are, how we are seen, and with whom we interact matter and, ultimately, play a substantial role in the creation of our ideas. ${ }^{162}$ The push for greater data transparency and replicability risks assuming that knowledge is valid only if the positionality of the knowledge producer is substitutable and, therefore, irrelevant. We suggest, instead, that many political scientists doing wide-ranging forms of research are operating through tribes that they construct and depend on in largely unique terms. Each tribe is singular, the product of complex power politics, and may be irreplicable, even with the most rigorous of research instruments and designs. That fact does not preclude greater transparency; on the contrary, we hope it invites more conversation, analogical thinking, and reflection of the kind we advance here.

\section{Notes}

1 Omari 2014.

2 Kaldor 1999; Kaldor 2013.

3 Mertus 2009, 165.

4 Sriram et al. 2009; Mazurana, Jacobsen, and Gale 2013.
5 Wood 2006; Thomson 2009; Fujii 2012. For a literature review, see Campbell 2010.

6 Barakat and Ellis 1996; Martin-Ortega and Herman 2009; Mazurana and Gale 2013; Hilhorst et al. 2016.

7 Carpenter 2012, 364; for recent debates about transparency in political science, see Isaac 2015.

8 Fine 1993.

9 Deeb and Winegar 2016, 2.

10 The "greater Middle East" is a geopolitical region inclusive of the Balkans, the Maghreb, the Horn of Africa, the "Middle East Core" countries, Afghanistan, and Pakistan (Bacevich 2016).

11 In this journal alone, see Goode 2010, Carpenter 2012, and McCann 2016; for examples of reflexivity in nonqualitative methods, see Tessler and Jamal 2006; Desposato 2014; Teele 2014; and Corstange 2015.

12 England 1994, 81.

13 Salzman 2002, 807.

14 Yanow and Schwartz-Shea 2015, xiv.

15 Wedeen 2010, 258.

16 de Waal 2009.

17 See Mukhopadhyay 2014; Malejacq 2016.

18 Stacey as quoted in England 1994, 85.

19 Goodhand 2000, 12.

20 Sultana 2007; Sirnate 2014.

21 Wax 1977, 322.

22 Kovats-Bernat 2002; see also Smith 1999; Fujii 2012, 718.

23 Carapico 2006; Fujii 2012.

24 Teele 2014, 115.

25 Carapico 2006, 430.

26 Peritore 1990.

27 Borland 1998, 317.

28 Hays-Mitchell 2010; Sriram 2009; Fujii 2010.

29 Clark 2006; Clarke 2010.

30 Driscoll 2015, 219.

31 Correspondence with authors, October 23, 2015 and August 15, 2016.

32 Cassell 1980, 31; L.L. Adams 1999, 332.

33 Haar, Heijmans, and Hilhorst 2013.

34 Diphoorn 2012, 213.

35 Kovats-Bernat 2002, 214; see also Hecht 1998.

36 L. L. Adams 1999, 341.

37 Vlassenroot 2006, 197.

38 Gerharz 2009, 8.

39 L. L. Adams 1999.

40 On the instrumentalization of spite, see Petersen 2011, 49-50.

41 Correspondence with authors, April 27, 2016.

42 Lederach 1995; International Commission on Intervention and State Sovereignty 2001; United Nations Secretary General's High-level Panel on Threats, Challenges and Change 2004.

43 Krasner 1999.

44 Mamdani 2009; Mamdani 2010. 
45 Suhrke 2007, 1293.

46 Ottaway 2003; Chandler 2006; Richmond 2006; Englebert and Tull 2008.

47 See for example Malejacq 2016.

48 Field Manual 3-24 2014, 8-5; for example, see Martin 2014, 1-2.

49 de Waal 2009, 108.

50 Thanks to a reviewer for helping us to clarify this point.

51 Fine 1993, 285-88.

52 Peritore 1990; Sluka 1991; J. H. Cohen 2000; Moser 2008.

53 Keohane as quoted in Carpenter 2012, 365.

54 Barakat and Ellis 1996, 155.

55 Carapico 2006, 429.

56 Goodhand 2000, 12.

57 Gerharz 2009, 12.

58 Peritore 1990, 359.

59 Carapico 2006, 430.

60 Hale 2001, 13.

61 Mosser 2010, 1079, 1081.

62 Carpenter 2012 and McCann 2016.

63 Deeb and Winegar 2016, ix-x.

64 Phone conversation with authors, September 27, 2015.

65 Jesse Driscoll, correspondence with authors, April 27, 2016; consider, for example, Andersen 2016.

66 Carapico 2006, 429-430.

67 For a discussion on objectivity, see Moser 2008.

68 Thompson 2009, 326.

69 Carpenter 2012, 368.

70 Dillman 1977, 406; Rabinow 1977.

71 N. Cohen and Arieli 2011, 430.

72 Clark 2006, 420.

73 Gerharz 2009, 6.

74 Tessler and Jamal 2006.

75 Corstange 2016.

76 U.S. army website, as quoted in American Anthropological Association Commission on the Engagement of Anthropology with the US Security and Intelligence Communities (CEAUSSIC) 2009; see also Gezari 2015.

77 Teele 2014, 116.

78 Fine 1993.

79 Brown 2009, 213.

80 Gerges 2009, 14.

81 Kilcullen 2005, 608; see also Kilcullen 2007; Kilcullen 2009.

82 On the concept of jihad, see, for example, Gerges 2005.

83 Anderson 2004; Dany 2014.

84 Donini 1995, 34.

85 de Torrente 2004. Dandoy and Pérouse de Montclos disagree and argue that, despite the perception that the risks to humanitarian aid workers have risen in the past two decades, "there is little evidence to suggest a relative increase of aid workers security incidents" (Dandoy and Pérouse de Montclos 2013, 353). This does not, we would argue, alter the communal perception of elevated danger as a function of association with particular political and military agendas and campaigns.

86 Abiew 2012, 203.

87 O'Brien 2004, 32.

88 de Torrente 2004, 2.

89 Vlassenroot 2006, 192.

90 Phone conversation with authors, September 27, 2015.

91 Tapper defines tribes as "localised groups in which kinship is the dominant idiom of organisation, and whose members consider themselves culturally distinct" (Tapper 1983, 9).

92 Tapper 1990, 51.

93 Bayart 1993, 220.

94 Geertz 1978; Barkey 1994; Chabal and Daloz 1999; Baldwin 2016.

95 Peritore 1990, 367.

96 Clark 2006, 419.

97 Sluka 1991; N. Cohen and Arieli 2011, 428-29; Romano 2006, 441; Norman 2009.

98 Peritore 1990; Hays-Mitchell 2001; Fujii 2010.

99 Tilly 2005.

100 Chakravarty 2012.

101 Peritore 1990, 366.

102 Brown 2009, 214-215.

103 Kovats-Bernat 2002.

104 Kovats-Bernat 2002, 212; see also Ross 2009.

105 Peritore 1990, 368.

106 Fine 1993.

107 Brown 2009, 214.

108 Brown 2009, 215, 213.

109 On this point, see Schwedler 2006, 427.

110 Sirnate 2014, 399.

111 On personality and positionality, see Moser 2008.

112 Lawrence 1937, 12-13.

113 Gant 2009.

114 Long 2008; Hughes and Tripodi 2009;

Mukhopadhyay 2014.

115 Bourgois 1990, 53.

116 J. Adams 1998.

117 Phone conversation with authors, September 27, 2015.

118 Price, Rubinstein, and Price 2012, 4.

119 Clark 2006, 420.

120 Fujii 2012, 720.

121 Fujii 2012, 720-21.

122 Johnson 1982; Borland 1998.

123 Junker quoted in Jarvie 1969, 505.

124 Clark 2006, 420.

125 Chakravarty 2012. 
126 Fine 1993, 271-272.

127 Gallaher 2009.

128 Bingham and Connors 2013, 198-99.

129 Dillman 1977, 406.

130 Townsend-Bell 2009.

131 Trigger, Forsey, and Meurk 2012.

132 N. Cohen and Arieli 2011, 428.

133 Vlassenroot 2006, 192.

134 Goffman 2014, 263; see also Schuessler 2015; Volokh 2015.

135 Diphoorn 2012, 218.

136 Diphoorn 2012, 204.

137 Robben 1995, 83.

138 Malejacq 2011.

139 Robben 1995.

140 Jarvie 1969.

141 Radsch 2009, 96-97.

142 Revkin 2016.

143 Stern and Berger 2016, 135.

144 Robben 1995, 85-86.

145 Robben 1995, 86.

146 Clark 2006, 418.

147 Shapiro and Weidmann 2015, 247.

148 Mansfield 2010; 2011; 2015.

149 De Juan and Bank 2015.

150 Cassell 1980, 33.

151 Autesserre 2014.

152 Goode 2010; see also Ahram 2013.

153 Kovats Bernats 2002, 214.

154 Romano 2006, 440.

155 Kovats-Bernat 2002, 214; see also Wood 2006, 380.

156 Paluck 2009.

157 Yanow and Schwartz-Shea 2008; Carpenter 2012, 364.

158 Isaac 2015, 274; 278.

159 Teele 2014, 169; see also Desposato 2014.

160 See, for example, Desposato 2016.

161 Zahar 2009, 191.

162 On the "interpretive turn," see Yanow and SchwartzShea 2015.

\section{References}

Abiew, Francis Kofi. 2012. "Humanitarian Action under Fire: Reflections on the Role of NGOs in Conflict and Post-Conflict Situations." International Peacekeeping 19(2): 203-16.

Adams, Jaqueline. 1998. "The Wrongs of Reciprocity: Fieldwork among Chilean Working-Class Women." Journal of Contemporary Ethnography 27(2): 219-41.

Adams, Laura L. 1999. “The Mascot Researcher.” Journal of Composite Materials 33(10): 928-40.

Ahram, Ariel. 2013. "Iraq in the Social Sciences: Testing the Limits of Research." Journal of the Middle East and Africa 4: 251-66.

American Anthropological Association Commission on the Engagement of Anthropology with the US Security and Intelligence Communities (CEAUSSIC). 2009.

"Final Report on The Army's Human Terrain System Proof of Concept Program."

Andersen, Travis. 2016. "New Subpoena Issued to Boston College in Belfast Project Case.” The Boston Globe, April 25.

Anderson, Kenneth. 2004. "Humanitarian Inviolability in Crisis: The Meaning of Impartiality and Neutrality 2003-2004 Afghanistan and Iraq Conflicts." Harvard 17 (41-74).

Autesserre, Séverine. 2014. Peaceland: Conflict Resolution and the Everyday Politics of International Intervention. New York: Cambridge University Press.

Bacevich, Andrew. 2016. America's War for the Greater Middle East: A Military History. New York: Random House.

Baldwin, Kate. 2016. "The Paradox of Chiefs.” In The Paradox of Traditional Chiefs in Democratic Africa, 3-19. Cambridge: Cambridge University Press.

Barakat, Sultan and Sue Ellis. 1996. "Researching under Fire: Issues for Consideration When Collecting Data and Information in War Circumstances, with Specific Reference to Relief and Reconstruction Projects." Disasters 20(2): 149-56.

Barkey, Karen. 1994. Bandits and Bureaucrats: The Ottoman Route to State Centralization. Ithaca, NY: Cornell University Press.

Bayart, Jean-François. 1993. The State in Africa: The Politics of the Belly. London; New York: Longman.

Bingham, Molly and Steve Connors. 2013. "Reporting the Story: Thoughts for Reporting on Violent Groups in a Turbulent Environment." In Research Methods in Conflict Settings: A View from Below, edited by Dyan Mazurana, Karen Jacobsen, and Lacey Gale, 169-220. New York: Cambridge University Press.

Borland, Katherine. 1998. "That's Not What I Said: Interpretative Conflict in Oral Narrative Research." In The Oral History Reader, edited by Robert Perks and Alistair Thomson, 2nd ed., 310-21. London: Routledge.

Bourgois, Philippe. 1990. "Confronting Anthropological Ethics: Ethnographic Lessons from Central America." Journal of Peace Research 27(1): 43-54.

Brown, Stephen. 2009. "Dilemmas of Self-Representation and Conduct in the Field." In Surviving Field Research: Working in Violent and Difficult Situations, edited by Chandra Lekha Sriram, John C. King, Julie A. Mertus, Olga Martin-Ortega, and Johanna Herman, 213-26. New York and London: Routledge.

Campbell, Susanna P. 2010. "Literature Review: Ethics of Research in Conflict and Post-Conflict Environments." Program on States and Security, The Graduate Center, City University, New York.

Carapico, Sheila. 2006. "No Easy Answers: The Ethics of Field Research in the Arab World." PS: Political Science \& Politics 39(3): 429-31. 
Carpenter, Charli. 2012. "'You Talk of Terrible Things So Matter-of-Factly in This Language of Science': Constructing Human Rights in the Academy." Perspectives on Politics 10(2): 363-83.

Cassell, Joan. 1980. "Ethical Principles for Conducting Fieldwork." American Anthropologist 82(1): 28-41.

Chabal, Patrick and Jean-Pascal Daloz. 1999. Africa Works: Disorder as Political Instrument. London: African International Institute.

Chakravarty, Anuradha. 2012. “'Partially Trusting' Field Relationships Opportunities and Constraints of Fieldwork in Rwanda's Postconflict Setting." Field Methods 24(3): 251-71.

Chandler, David. 2006. "Back to the Future? The Limits of Neo-Wilsonian Ideals of Exporting Democracy." Review of International Studies 32: 475-94.

Clark, Janine A. 2006. "Field Research Methods in the Middle East." PS: Political Science \& Politics 39(3): 417-24.

Clarke, Kamari M. 2010. "Toward a Critically Engaged Ethnographic Practice." Current Anthropology 51(S2): S301-S12.

Cohen, Jeffrey H. 2000. "Problems in the Field: Participant Observation and the Assumption of Neutrality." Field Methods 12(4): 316-33.

Cohen, Nissim and Tamar Arieli. 2011. "Field Research in Conflict Environments: Methodological Challenges and Snowball Sampling." Journal of Peace Research 48(4): 423-35.

Corstange, Daniel. 2016. "Anti-American Behavior in the Middle East: Evidence from a Field Experiment in Lebanon." Journal of Politics 78(1): 311-25.

Dandoy, Arnaud and Marc-Antoine Pérouse de Montclos. 2013. "Humanitarian Workers in Peril? Deconstructing the Myth of the New and Growing Threat to Humanitarian Workers." Global Crime 14 (4): 341-58.

Dany, Charlotte. 2014. "Beyond Principles vs. Politics: Humanitarian Aid in the European Union." ARENA Working Paper II (November).

Deeb, Lara and Jessica Winegar. 2016. Anthropology's Politics: Disciplining the Middle East. Stanford: Stanford University Press.

De Juan, Alexander and André Bank. 2015. “The Ba'athist Blackout? Selective Goods Provision and Political Violence in the Syrian Civil War." Journal of Peace Research 52(1): 91-104.

de Torrente, Nicolas. 2004. "Humanitarian Action Under Attack: Reflections on the Iraq War." Harvard Human Rights Journal 17(1): 1-39.

de Waal, Alex. 2009. "Mission without End? Peacekeeping in the African Political Marketplace." International Affairs 85(1): 99-113.

Desposato, Scott W. 2014. "Ethical Challenges and Some Solutions for Field Experiments:” 1-11.
Desposato, Scott W., ed. 2016. Ethics and Experiments: Problems and Solutions for Social Scientists and Policy Professionals. New York and London: Routledge.

Dillman, Caroline M. 1977. "Ethical Problems in Social Science Research Peculiar to Participant Observation." Human Organization 36(4): 405-07.

Diphoorn, Tessa. 2012. "The Emotionality of Participation: Various Modes of Participation in Ethnographic Fieldwork on Private Policing in Durban, South Africa." Journal of Contemporary Ethnography 42(2): 201-25.

Donini, Antonio. 1995. "Beyond Neutrality: On the Compatibility of Military Intervention and Humanitarian Assistance." The Fletcher Forum of World Affairs 19(2): 31-45.

Driscoll, Jesse. 2015. Warlords and Coalition Politics in PostSoviet States. Cambridge: Cambridge University Press.

England, Kim V. L. 1994. "Getting Personal: Reflexivity, Positionality, and Feminist Research." The Professional Geographer 46(1): 80-89.

Englebert, Pierre and Denis M. Tull. 2008. "Postconflict Reconstruction in Africa: Flawed Ideas about Failed States." International Security 32(4): 106-39.

Field Manual 3-24. 2014. "Insurgencies and Countering Insurgencies." Washington, D.C.: Active Army, Army National Guard, and U.S. Army Reserve.

Fine, Gary Alan. 1993. "Ten Lies of Ethnography: Moral Dilemmas of Field Research." Journal of Contemporary Ethnography 22(3): 267-94.

Fujii, Lee Ann. 2010. "Shades of Truth and Lies: Interpreting Testimonies of War and Violence.” Journal of Peace Research 47(2): 231-41.

. 2012. "Research Ethics 101: Dilemmas and Responsibilities." PS: Political Science \& Politics 45(4): 717-23.

Gallaher, Carolyn. 2009. "Researching Repellent Groups: Some Methodological Considerations on How to Represent Militants, Radicals, and Other Belligerents." In Surviving Field Research: Working in Violent and Difficult Situations, edited by Chandra Lekha Sriram, John C. King, Julie A. Mertus, Olga Martin-Ortega, and Johanna Herman, 127-46. New York: Routledge.

Gant, Jim. 2009. "A Strategy for Success in Afghanistan: One Tribe at a Time." Los Angeles: Nine Sisters Imports. Geertz, Clifford. 1978. "The Bazaar Economy : Information and Search in Peasant Marketing." The American Economic Review 68(2): 28-32.

Gerges, Fawaz A. 2009. The Far Enemy: Why Jihad Went Global. 2nd ed. Cambridge: Cambridge University Press. Gerharz, Eva. 2009. “Ambivalent Positioning: Reflections on Ethnographic Research in Sri Lanka during the Ceasefire of 2002." 361. Working Papers in Development Sociology and Social Anthropology. Bielefeld.

Gezari, Vanessa M. 2015. The Tender Soldier: A True Story of War and Sacrifice. New York: Simon \& Schuster. 
Goffman, Alice. 2014. On the Run: Fugitive Life in an American City. Chicago: University of Chicago Press.

Goode, J. Paul. 2010. "Redefining Russia: Hybrid Regimes, Fieldwork, and Russian Politics." Perspectives on Politics 8(4): 1055-75.

Goodhand, Jonathan. 2000. "Research in Conflict Zones: Ethics and Accountability." Forced Migration 8(4): 12-15.

Haar, Gemma Van Der, Annelies Heijmans, and Dorothea Hilhorst. 2013. "Interactive Research and the Construction of Knowledge in Conflict-Affected Settings." Disasters 37(1): 20-35.

Hale, Charles R. 2001. "What Is Activist Research?” Items and Issues: Social Science Research Council 2(1): 13-15.

Hays-Mitchell, Maureen. 2001. "Danger, Fulfillment, and Responsibility in a Violence-Plagued Society." Geographical Review 91(1-2): 311-21.

Hecht, Tobias. 1998. At Home in the Street: Street Children of Northeast Brazil. Cambridge: Cambridge University Press.

Hilhorst, Dorothea, Lucy Hodgson, Bram Jansen, and Rodrigo Mena. 2016. Security Guidelines for Field Researchers in Complex, Remote and Hazardous Places. The Hague: International Institute of Social Studies.

Hughes, Geraint and Christian Tripodi. 2009. "Anatomy of a Surrogate: Historical Precedents and Implications for Contemporary Counter-Insurgency and CounterTerrorism." Small Wars \& Insurgencies 20(1): 1-35.

International Commission on Intervention and State Sovereignty. 2001. "The Responsibility to Protect." Ottawa.

Isaac, Jeffrey C. 2015. "For a More Public Political Science." Perspectives on Politics 13(2): 269-83.

Jarvie, Ian Charles. 1969. "The Problem of Ethical Integrity in Participant Observation." Current Anthropology 10(5): 505-08.

Johnson, Carole Gaar. 1982. "Risks in the Publication of Fieldwork." In The Ethics of Social Research: Fieldwork, Regulation, and Publication, edited by Joan Sieber, 71-91. New York: Springer-Verlag.

Kaldor, Mary. 1999. New and Old Wars: Organized Violence in a Global Era. Cambridge: Polity Press. 2013. "In Defence of New Wars." Stability: International Journal of Security and Development 2(1), 4: 1-16.

Kilcullen, David. 2005. "Countering Global Insurgency." Journal of Strategic Studies 28(4): 597-617.

2009. The Accidental Guerrilla: Fighting Small Wars in the Midst of a Big One. New York: Oxford University Press.

Kovats-Bernat, J. Christopher. 2002. "Negotiating Dangerous Fields: Pragmatic Strategies for Fieldwork Mid Violence and Terror." American Anthropologist 104(1): 208-22.

Krasner, Stephen D. 1999. Sovereignty: Organized Hypocrisy. Princeton: Princeton University Press.

Lawrence, T. E. 1937. Seven Pillars of Wisdom. Wordsworth Editions Ltd.
Lederach, John Paul. 1995. Preparing for Peace: Conflict Transformation Across Cultures. New York: Syracuse University Press.

Long, Austin. 2008. "The Anbar Awakening." Survival 50(2): 67-94.

Malejacq, Romain. 2011. "Meeting with a Warlord." Afghanopoly. July 20. https://afghanopoly.wordpress. com/2011/07/20/meeting-with-a-warlord/.

. 2016. "Warlords, Intervention, and State Consolidation: A Typology of Political Orders in Weak and Failed States." Security Studies 25(1): 85-110.

Mamdani, Mahmood. 2009. Saviors and Survivors: Darfur, Politics, and the War on Terror. New York: Pantheon.

2010. "Responsibility to Protect or Right to Punish?" Journal of Intervention and Statebuilding 4(1): 53-67.

Mansfield, David. 2010. "Where Have All the Flowers Gone? Assessing the Sustainability of Current Reductions in Opium Production in Afghanistan.” Kabul: Afghanistan Research and Evaluation Unit. . 2011. "Between a Rock and a Hard Place: Counter-Narcotics Efforts and Their Effects in Nangarhar and Helmand in the 2010-2011 Growing Season." Kabul: Afghanistan Research and Evaluation Unit.

. 2015. "Effective Monitoring and Evaluation in Conflict-Affected Environments: Afghanistan Post-2014.” Washington DC: U.S. Institute of Peace. Martin-Ortega, Olga and Johanna Herman. 2009. "There and Back: Surviving Field Research in Violent and Difficult Situations." In Surviving Field Research: Working in Violent and Difficult Situations, edited by Chandra Lekha Sriram, John C. King, Julie A. Mertus, Olga Martin-Ortega, and Johanna Herman, 227-41. New York: Routledge.

Martin, Mike. 2014. An Intimate War: An Oral History of the Helmand Conflict. London: C. Hurst \& Co.

Mazurana, Dyan and Lacey Andrews Gale. 2013. "Preparing for Research in Active Conflict Zones." In Research Methods in Conflict Settings: A View from Below, edited by Dyan Mazurana, Karen Jacobsen, and Lacey Gale, 277-92. New York: Cambridge University Press.

Mazurana, Dyan, Karen Jacobsen, and Lacey Gale, ed. 2013. Research Methods in Conflict Settings: A View from Below. New York: Cambridge University Press.

McCann, Michael. 2016. "Labor Scholarship And/as Labor Activism." Perspectives on Politics 14(2): 432-41.

Mertus, Julie A. 2009. "Maintenance of Personal Security: Ethical and Operational Issues." In Surviving Field Research: Working in Violent and Difficult Situations, edited by Chandra Lekha Sriram, John C. King, Julie A. Mertus, Olga Martin-Ortega, and Johanna Herman, 165-76. New York: Routledge.

Moser, Sarah. 2008. "Personality: A New Positionality?" Area 40(3) (September): 383-92. 
Mosser, Michael W. 2010. "Puzzles versus Problems: The Alleged Disconnect between Academics and Military Practitioners." Perspectives on Politics 8(4): 1077-86.

Mukhopadhyay, Dipali. 2014. Warlords, Strongman Governors, and the State in Afghanistan. Cambridge: Cambridge University Press.

Norman, Julie M. 2009. "Got Trust? The Challenge of Gaining Access in Conflict Zones.” In Surviving Field Research: Working in Violent and Difficult Situations, edited by Chandra Lekha Sriram, John C. King, Julie A. Mertus, Olga Martin-Ortega, and Johanna Herman, 71-90. New York: Routledge.

O’Brien, Paul. 2004. "Politicized Humanitarianism: A Response to Nicolas de Torrente." Harvard Human Rights Journal 17(1): 31-40.

Omari, Shazdeh. 2014. "International Journalists Killed at High Rate in 2014: Middle East Deadliest Region." Committee to Protect Journalists.

Ottaway, Marina. 2003. "Promoting Democracy after Conflict: The Difficult Choices." International Studies Perspectives 4(3): 314-22.

Paluck, Elizabeth Levy. 2009. "Methods and Ethics with Research Teams and NGOs: Comparing Experiences across the Border of Rwanda and Democratic Republic of Congo." In Surviving Field Research: Working in Violent and Difficult Situations, edited by Chandra Lekha Sriram, John C. King, Julie A. Mertus, Olga Martin-Ortega, and Johanna Herman, 38-56. New York: Routledge.

Paris, Roland. 2004. At War's End: Building Peace after Civil Conflict. New York: Cambridge University Press.

Peritore, N. Patrick. 1990. "Reflections on Dangerous Fieldwork." The American Sociologist 21(4): 359-72.

Petersen, Roger D. 2011. Western Intervention in the Balkans: The Strategic Use of Emotions in Conflict. Cambridge: Cambridge University Press.

Price, Michael, Robert A. Rubinstein, and David H. Price. 2012. “Material Support': US Anti-Terrorism Law Threatens Human Rights and Academic Freedom.” Anthropology Today 28(1): 3-5.

Rabinow, Paul. 1977. Reflections on Fieldwork in Morocco. Berkeley: University of California Press.

Radsch, Courtney. 2009. "From Cell Phones to Coffee: Issues of Access in Egypt and Lebanon." In Surviving Field Research: Working in Violent and Difficult Situations, edited by Chandra Lekha Sriram, John C. King, Julie A. Mertus, Olga Martin-Ortega, and Johanna Herman, 91-107. New York: Routledge.

Revkin, Mara. 2016. "ISIS' Social Contract: What the Islamic State Offers Civilians." Foreign Affairs, January 10.

Richmond, Oliver P. 2006. "The Problem of Peace: Understanding the 'Liberal Peace."' Conflict, Security \& Development 6(3): 291-314.

Robben, Antonius C. G. M. 1995. "The Politics of Truth and Emotion among Victims and Perpetrators of Violence." In Fieldwork under Fire: Contemporary
Studies of Violence and Survival, edited by Carolyn Nordstrom and Antonius C. G. M. Robben, 81-103. Berkeley; Los Angeles: University of California Press.

Romano, David. 2006. "Conducting Research in the Middle East's Conflict Zones.” PS: Political Science \& Politics 39(3): 439-41.

Ross, Amy. 2009. "Impact on Research of SecuritySeeking Behaviour." In Surviving Field Research: Working in Violent and Difficult Situations. edited by Chandra Lekha Sriram, John C. King, Julie A. Mertus, Olga Martin-Ortega, and Johanna Herman, 177-88. New York: Routledge.

Salzman, Philip Carl. 2002. “On Reflexivity.” American Anthropologist 104(3): 805-13.

Schuessler, Jennifer. 2015. "Alice Goffman's Heralded Book on Crime Is Disputed." New York Times, June 5. Schwedler, Jillian. 2006. "The Third Gender: Western Female Researchers in the Middle East." PS: Political Science \& Politics 39(3): 425-28.

Shapiro, Jacob and Nils B. Weidmann. 2015. "Is the Phone Mightier than the Sword? Cell Phones and Insurgent Violence in Iraq." International Organization 69(2): 247-74. Sirnate, Vasundhara. 2014. "Positionality, Personal Insecurity, and Female Empathy in Security Studies Research.” PS: Political Science \& Politics 47(2): 398-401.

Sluka, Jeffrey A. 1991. "Reflections on Managing Danger in Fieldwork: Dangerous Anthropology in Belfast." In Fieldwork under Fire: Contemporary Studies of Violence and Survival, edited by C. Nordstrom and A. C. G. M. Robben, 276-94. Berkeley; Los Angeles: University of California Press.

Smith, Linda Thuhiwai. 1999. Decolonizing Methodologies: Research and Indigenous Peoples. London: Zed Books.

Sriram, Chandra Lekha. 2009. "Maintenance of Standards of Protection during Writeup and Publication." In Surviving Field Research: Working in Violent and Difficult Situations, edited by Chandra Lekha Sriram, John C. King, Julie A. Mertus, Olga Martin-Ortega, and Johanna Herman, 57-68. New York: Routledge.

Sriram, Chandra Lekha, John C. King, Julie A. Mertus, Olga Martin-Ortega, and Johanna Herman. 2009. Surviving Field Research: Working in Violent and Difficult Situations. New York: Routledge.

Stern, Jessica and J. M. Berger. 2016. ISIS: The State of Terror. London: William Collins.

Suhrke, Astri. 2007. "Reconstruction as Modernisation: The 'post-Conflict' Project in Afghanistan." Third World Quarterly 28(7): 1291-1308.

Sultana, Farhana. 2007. "Reflexivity, Positionality and Participatory Ethics: Negotiating Fieldwork Dilemmas in International Research." ACME: An International E-Journal for Critical Geographies 6(3): 374-85.

Tapper, Richard. 1983. "Introduction." In The Conflict of Tribe and State in Iran and Afghanistan, edited by Richard Tapper, 1-82. London: Croom Helm. 
1990. "Anthropologists, Historians, and Tribespeople on Tribe and State Formation in the Middle East." In Tribes and State Formation in the Middle East, edited by Philip S. Khoury and Joseph Kostiner, 48-73. Berkeley: University of California Press.

Teele, Dawn Langan. 2014. "Reflections on the Ethics of Field Experiments." In Field Experiments and Their Critics: Essays on the Uses and Abuses of Experimentation in the Social Sciences, edited by Dawn Langan Teele, 115-40. New Haven: Yale University Press.

Tessler, Mark and Amaney Jamal. 2006. "Political Attitude Research in the Arab World: Emerging Opportunities." PS: Political Science of Politics 39(3): 433-37.

Thompson, Marshall. 2009. "Research, Identities, and Praxis: The Tensions of Integrating Identity into the Field Experience." PS: Political Science \& Politics 42(2): 325-28.

Thomson, Susan M. 2009. "Why Develop Guidelines on Ethics in Post-War Field Research?" Ottawa.

Tilly, Charles. 2005. Trust and Rule. Cambridge: Cambridge University Press.

Townsend-Bell, Erica. 2009. "Being True and Being You: Race, Gender, Class, and the Fieldwork Experience." PS: Political Science \& Politics 42(2): 311-14.

Trigger, David, Martin Forsey, and Carla Meurk. 2012. "Revelatory Moments in Fieldwork." Qualitative Research 12(5): 513-27.

United Nations Secretary General's High-level Panel on Threats, Challenges and Change. 2004. "A More Secure World: Our Shared Responsibility.” New York.
Vlassenroot, Koen. 2006. "War and Social Research: The Limits of Empirical Methodologies in War-Torn Environments." Civilisations 54(1-2): 191-98.

Volokh, Eugene. 2015. "Prof. Alice Goffman, 'On the Run,' and Driving a Gang Member Around, Looking for a Mutual Friend's Killer." Washington Post, June 2.

Wax, Murray L. 1977. "On Fieldworkers and Those Exposed to Fieldwork: Federal Regulations and Moral Issues." Human Organization (36): 321-28.

Wedeen, Lisa. 2010. "Refletions on Ethnographic Work in Political Science." Annual Review of Political Science 13(1): 255-72.

Wood, Elisabeth Jean. 2006. "The Ethical Challenges of Field Research in Conflict Zones." Qualitative Sociology 29(3): 373-86.

Yanow, Dvora and Peregrine Schwartz-Shea. 2008.

"Reforming Institutional Review Board Policy: Issues in Implementation and Field Research.” PS: Political Science \& Politics 41(3): 483-94.

2015. "Wherefore 'Interpretive:' An Introduction." In Interpretation and Method: Empirical Research Methods and the Interpretive Turn, 2nd ed., xiii-xxxi. Oxon and New York: Routledge.

Zahar, Marie-Joëlle. 2009. "Fieldwork, Objectivity and the Academic Enterprise." In Surviving Field Research: Working in Violent and Difficult Situations, edited by Chandra Lekha Sriram, John C. King, Julie A. Mertus, Olga Martin-Ortega, and Johanna Herman, 191-212. New York: Routledge. 